\title{
Diagnosing the extreme surface melt event over southwestern Greenland in 2007
}

\author{
M. Tedesco ${ }^{1,2,3}$, M. Serreze ${ }^{4}$, and X. Fettweis ${ }^{5}$ \\ ${ }^{1}$ City College of New York, City University of New York, New York, NY, 10031, USA \\ ${ }^{2}$ NASA Goddard Space Flight Center, Greenbelt, MD, 20771, USA \\ ${ }^{3}$ University of Maryland, Baltimore County, Baltimore, MD, 21250, USA \\ ${ }^{4}$ Cooperative Institute for Research in Environmental Sciences, University of Colorado, Boulder, CO 80309, USA \\ ${ }^{5}$ Département de Géographie, Université de Liège, Belgium
}

Received: 7 April 2008 - Published in The Cryosphere Discuss.: 29 May 2008

Revised: 5 September 2008 - Accepted: 25 September 2008 - Published: 19 November 2008

\begin{abstract}
Analysis of passive microwave brightness temperatures from the space-borne Special Sensor Microwave Imager (SSM/I) documents a record surface snowmelt over high elevations (above $2000 \mathrm{~m}$ ) of the Greenland ice sheet during summer of 2007. To interpret this record, results from the SSM/I are examined in conjunction with fields from the National Centers for Environmental Prediction/National Center for Atmospheric Research reanalysis and output from a regional climate model. The record surface melt reflects unusually warm conditions, seen in positive summertime anomalies of surface air temperatures, downwelling longwave radiation, $1000-500 \mathrm{hPa}$ atmospheric thickness, and the net surface energy flux, linked in turn to southerly airflow over the ice sheet. Low snow accumulation may have contributed to the record through promoting anomalously low surface albedo.
\end{abstract}

\section{Introduction}

The most visible evidence of Arctic environmental change is its rapidly shrinking sea ice cover. Based on analysis of time series that combine records from the space-borne Scanning Multichannel Microwave Radiometer (SMMR, 1979-1987) and the Special Sensor Microwave/Imager (SSM/I, 19882007) negative trends in northern hemisphere sea ice extent encompass all months (Serreze et al., 2007). The summer

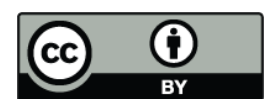

Correspondence to: $\mathrm{M}$. Tedesco (mtedesco@sci.ccny.cuny.edu) and autumn of 2007 serve as exclamation points on these trends, with ice extent falling to new record lows (Comiso et al., 2008; Stroeve et al., 2008). Interestingly, this event was attended by record summer surface snowmelt over the Greenland ice sheet, also punctuating a general trend. This is seen in the analyses of both Tedesco (2007a) and Mote (2007) based on satellite data and supported by ground measurements (Van de Broeke et al., 2008). The record identified by Tedesco (2007) is based on an annual surface melting index (MI, the product of melt area and the number of melting days) for the part of the ice sheet above $2000 \mathrm{~m}$, based on SSM/I data. Mote (2007) focused on a functionally similar index computed for the entire ice sheet, assessed from a time series combining records from SSM/I, SMMR and the Electrically Scanning Microwave Radiometer (ESMR, 1973, 1974 and 1976). The present paper addresses the causes of the record 2007 surface melt.

Variations in the extent and duration of summer melt over Greenland reflect a suite of processes intimately tied to the surface energy and mass balance. Horizontal atmospheric heat transports are important through impacts on the longwave radiation to the surface and vertical turbulent heat fluxes. Cloud cover reduces shortwave radiation to the surface, but tends to increase the downwelling longwave component. Surface albedo is key, through both influencing solar radiation absorbed by the surface and by modulating cloud radiative forcing. Albedo can be highly variable, and tends to decrease through the melt season as snow grain sizes increase as a consequence of constructive metamorphism. We evaluate the mechanisms contributing to the record surface melt identified by Tedesco (2007a) through analysis of surface air

Published by Copernicus Publications on behalf of the European Geosciences Union. 


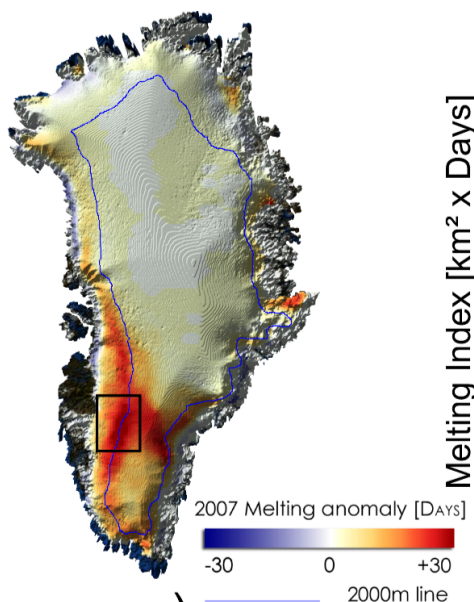

a)

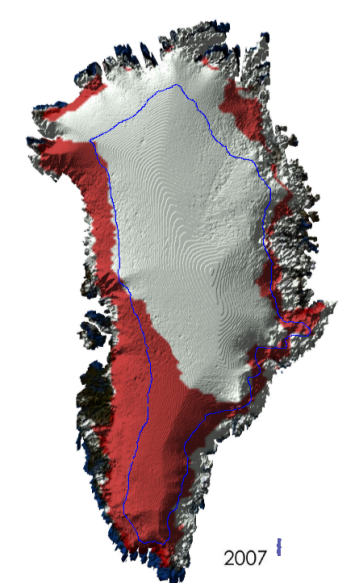

c)

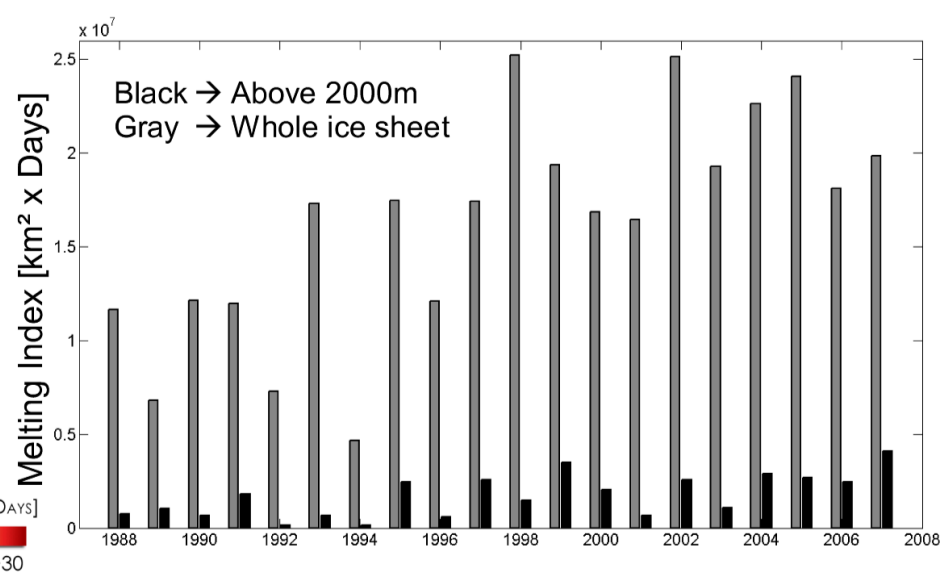

b)

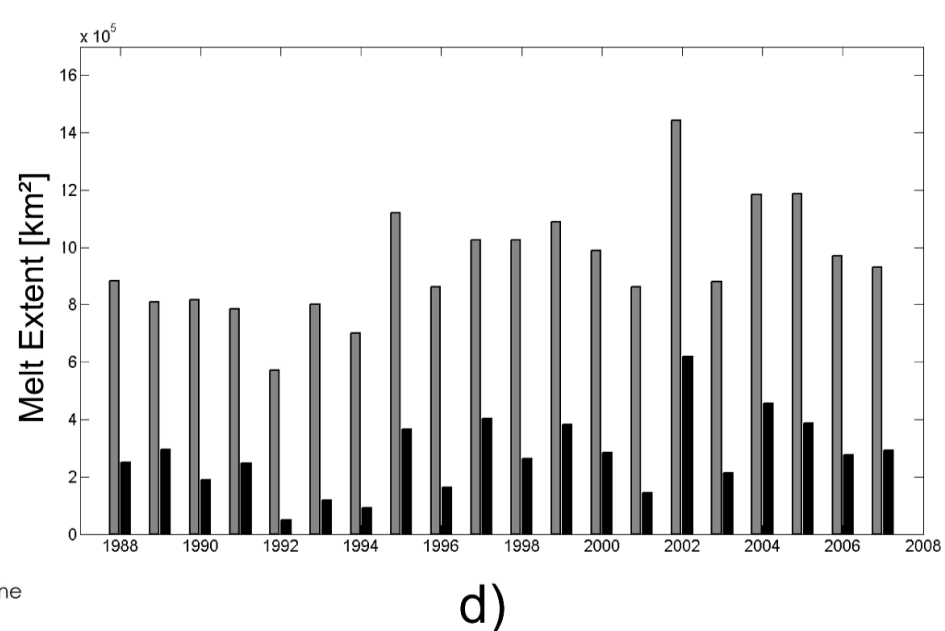

Fig. 1. (a) Map of 2007 melting days anomalies (number of melting days in 2007 minus the average number of melting days for the period 1988-2006); (b) annual melting index time series for areas above $2000 \mathrm{~m}$ (black) and the entire ice sheet (grey); (c) map of 2007 melt extent (melting occurring for at least one day); (d) melt extent time series for areas above $2000 \mathrm{~m}$ (black) and the entire ice sheet (grey).

temperature and circulation fields from the National Centers for Environmental Research (NCEP/NCAR) reanalysis (Kalnay et al., 1996) in conjunction with anomalies in components of the surface energy balance depicted by the regional climate model MAR (for Modèle Atmosphérique Régional) (Fettweis, 2007). We focus first on the ice sheet as a whole and then turn attention to its southwest portion, where surface melt anomalies reached their largest positive values. Our MAR application complements a number of past studies examining the mass balance and climate of Greenland using regional climate models (e.g., Box et al., 2004; Lefebre et al., 2003).

\section{Surface melting for summer 2007}

The microwave brightness temperature over dry snow is relatively low compared to when snow is wet. When snow melts, liquid meltwater forms in the snow pack and an increase in the emitted microwave radiation occurs (Ulaby and Stiles, 1980), mainly as a consequence of the increased imaginary part of snow permittivity which, in turn, also leads to an increase in the absorption. Changes in melt duration and extent over Greenland have been examined via various techniques using passive microwave data, including the seasonal change in emissivity (Mote and Anderson, 1995; Mote, 2007), the frequency dependence of emissivity (Abdalati and Steffen, 1997; Steffen et al., 2004) and the diurnal change in brightness temperature using ascending and 

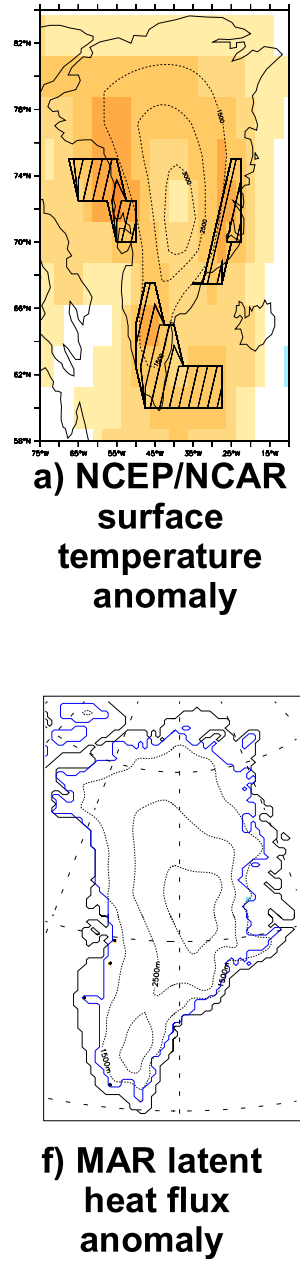
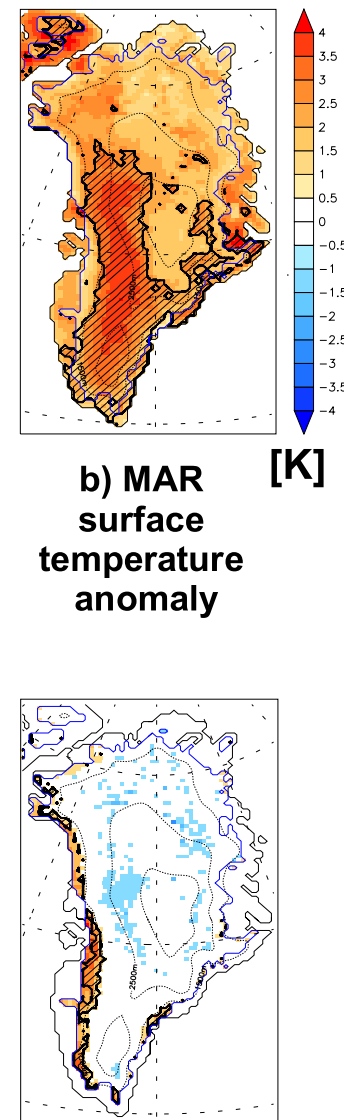
g) MAR sensible heat flux anomaly

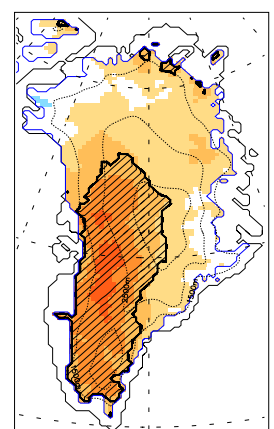

c) MAR longwave incoming anomaly
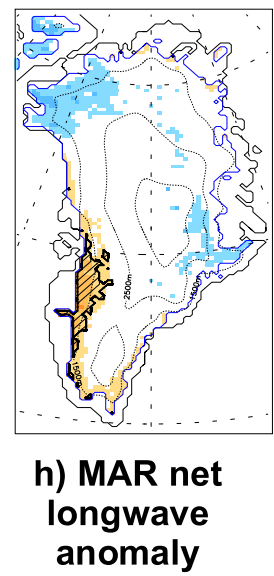

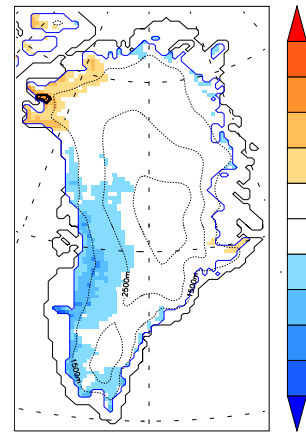

d) MAR shortwave incoming anomaly

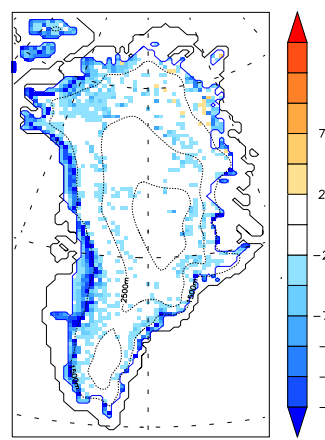

e) MAR albedo anomaly
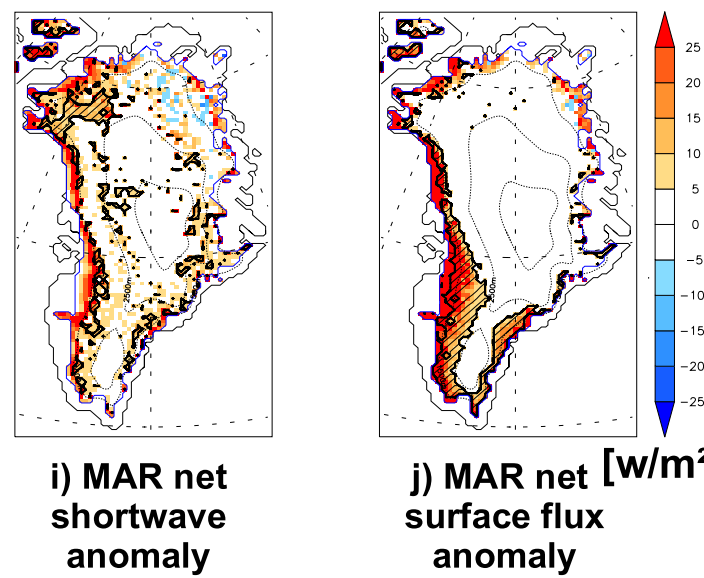

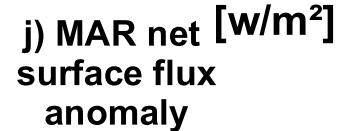

Fig. 2. Summer (June-August) anomaly maps, referenced to 1988-2006 means, of: (a) surface air temperature from NCEP/NCAR; (b) surface air temperature from the MAR; $(\mathbf{c}-\mathbf{j})$ incoming longwave radiation, incoming shorwave radiation, albedo, latent heat flux, sensible heat flux, net longwave radiation, net shortwave radiation and the net surface energy flux as simulated by the MAR. Significant anomalies (those at least twice the magnitude of the 1988-2006 standard deviation) are hatched and bounded by bold black lines. Surface flux anomalies are only plotted for pixels defined as ice-covered in the MAR model. The ice sheet margin is drawn in dark blue.

descending orbital passes (Tedesco, 2007a,b). Here, we use SSM/I brightness temperatures at $19.35 \mathrm{GHz}$, horizontal polarization, available at $25 \mathrm{~km}$ resolution from the National Snow and Ice Data Center (Armstrong et al., 1994). Building on Tedesco (2007a), panels a and b of Fig. 1 show, respectively, the spatial distribution of melting day anomalies in 2007 (number of melting days in 2007 at each grid cell minus the average for the period 1988-2006) and time series of the annual MI for the ice sheet as a whole (gray bars) and for regions above $2000 \mathrm{~m}$ (black bars). To obtain the annual MI, the number of melting days for each pixel is first multiplied by the pixel area $\left(\sim 625 \mathrm{~km}^{2}\right)$. These values are then summed for all pixels experiencing melt. Panels $\mathrm{c}$ and $\mathrm{d}$ show the 2007 melt extent (areas where melting occurred for at least one day) and its time series.
The key feature of 2007 in this analysis is the high melting index at the higher ice sheet elevations. For the ice sheet as a whole, the annual MI for 2007 was $30 \%$ above average but still well below peak values estimated for 1998 and 2002. However, the MI above $2000 \mathrm{~m}$ set a new record of $4008750 \mathrm{~km}^{2} \times$ days, beating the previous high of $3486875 \mathrm{~km}^{2} \times$ days set in 1999 . From Fig. 1a, it is apparent that some areas in the southwest part of the ice sheet experienced melting up to 25-30 days longer than average (redder colors). Updated through 2007, the linear trend in the MI above $2000 \mathrm{~m}$ stands at $126487 \mathrm{~km}^{2} \times$ days/yr, significant at the $95 \%$ confidence level.

Mote (2007) presents a map similar to Fig. 1a, but with melting day anomalies for 2007 calculated with respect to the longer record (1973-2007) that includes SMMR and ESMR. 

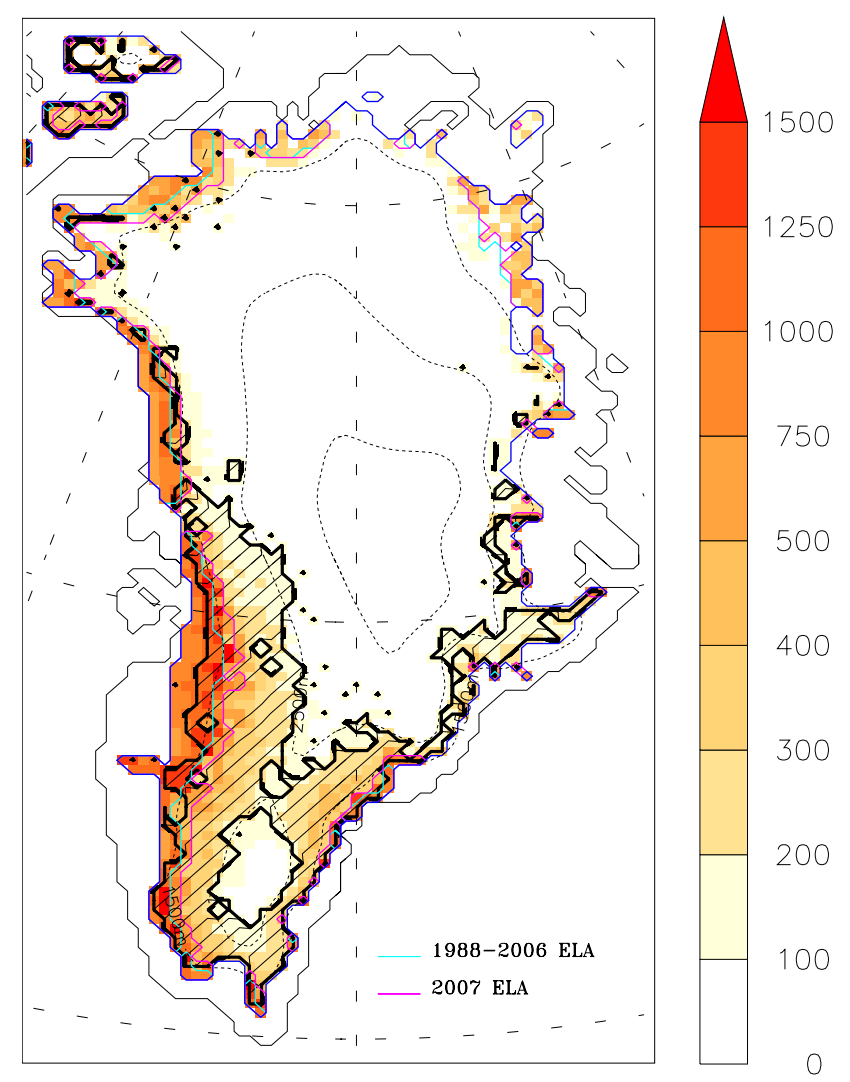

The 2007 meltwater anomaly (mmWE)

Fig. 3. The 2007 available meltwater anomaly (referenced to 1988 2006 means) simulated by MAR. Units are mm of water equivalent. Part of the simulated meltwater re-freezes in the snowpack and is hence unavailable for runoff (Lefebre et al., 2003). Significant anomalies (those at least twice the magnitude of the 19882006 standard deviation) are hatched and bounded by bold black lines. Anomalies are only plotted for pixels defined as ice-covered in the MAR model. The simulated Equilibrium Line Altitude (ELA, where the surface mass balance is zero) averaged for 1988-2006 and for 2007 is also shown.

The major difference compared to Fig. 1a is that the area with strong positive departures over southwestern Greenland extends further east. Peak departures are also larger, locally exceeding 50 days with melting. This reflects differences in both the baseline period for computing anomalies and analysis techniques (notably an emission model using scattering coefficients that are empirically derived from brightness temperatures before the onset of melt each year.

Instead of a MI (Fig. 1b) Mote (2007) provides time series of seasonal melt departures (SMD) assessed for the entire ice sheet, in which daily departures in melt extent, calculated with respect to 1973-2007 means, are summed through each melt season. While functionally similar to the MI here presented, the SMD approach is designed to mitigate the ef- fects of missing days in the satellite records, most problematic for SMMR and ESMR. From the SMD time series, the record melt of 2007 stands out more prominently than shown in Fig. 1b, with 1998 representing the previous record.

\section{Addressing the causes of the record melt}

Panels $a$ and $b$ of Fig. 2 show the spatial pattern of $2 \mathrm{~m}$ (hereafter surface air) temperature anomalies $(\mathrm{K})$ from the NCEP/NCAR reanalysis and as simulated by the MAR, averaged for summer (June through August, JJA) 2007. Anomalies are calculated with respect to 1988-2006 JJA averages. The surface air temperature in the NCEP/NCAR reanalysis represents interpolation between the lowest model analysis level and the modeled surface skin temperature. MAR (Gallée and Schayes, 1994) is coupled to the 1-D Soil Ice Snow Vegetation Atmosphere Transfer (SISVAT) scheme (De Ridder and Gallée, 1998). Fettweis (2007) examined a 28-year surface mass balance simulation (1979-2006) over the ice sheet with the MAR at a horizontal resolution of $25 \mathrm{~km}$. For the present paper, we extended this simulation to the end of 2007. Data from the European Centre for Medium Range Weather Forecasts (ECMWF, http://www.ecmwf.int/) ERA-40 reanalysis (1977-2002) and ECMWF operational analyses (2002-2007) were used to initialize meteorological fields at the beginning of the MAR simulation and to force the lateral boundaries every six hours during the simulation. The surface albedo and other parameterizations used in the MAR snow model are described in Lefebre et al. (2003).

Both NCEP/NCAR and the MAR indicate that surface air temperature was above the average over most of the ice sheet (see Fig. 2a-b). Warming is more pronounced above the ice sheet in the MAR model than along its margin. In addition, anomalies are more strongly positive in the MAR simulation compared to NCEP/NCAR, particularly over the higher ice sheet elevations where they may exceed $3^{\circ} \mathrm{C}$. The location of the peak anomalies in MAR also coincide more closely with the region of peak melting day anomalies seen in Fig. 1a. This may reflect the higher resolution of MAR compared to the NCEP/NCAR fields, its more robust treatment of the surface energy balance, as well as differences in the depiction of regional circulation between NCEP/NCAR and the operational ECMWF fields used as boundary forcing for MAR. Note that the spatial pattern of meltwater production anomalies as simulated by MAR (see Fig. 3) is in good agreement with the pattern of melting day anomalies shown in Fig. 1.

Figure 2c-e shows corresponding anomalies of incoming longwave and shortwave radiation at the surface $\left(\mathrm{W} \mathrm{m}^{-2}\right)$, and surface albedo (\%), as simulated by MAR. Incoming longwave radiation anomalies $\left(\mathrm{W} \mathrm{m}^{-2}\right)$ are positive over most of the ice sheet, significant and largest on the western side where they reach $+22 \mathrm{~W} \mathrm{~m}^{-2}$. Air temperature, cloud properties and humidity may all be contributing to these anomalies. Consistent with negative anomalies in simulated 

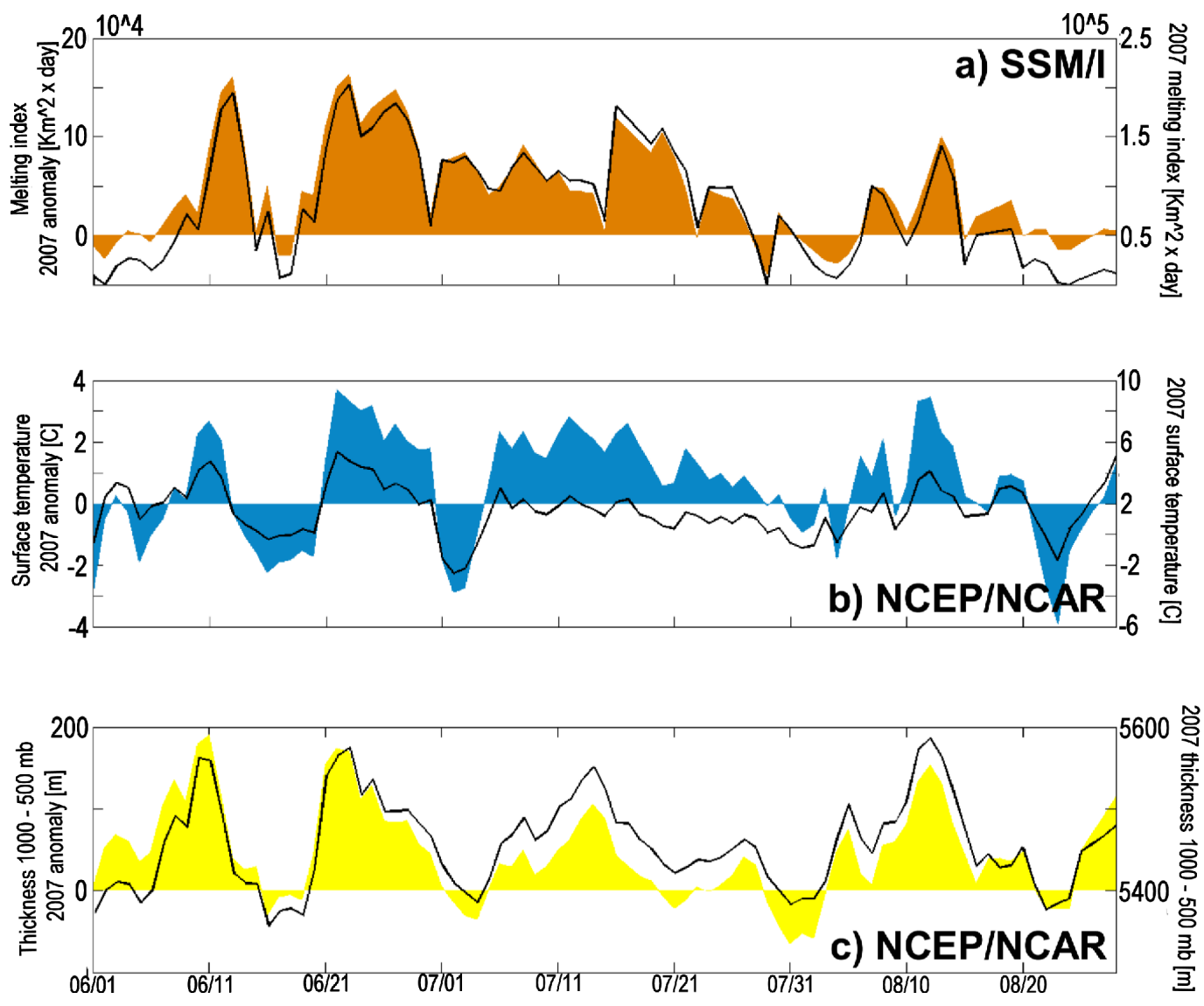

Fig. 4. Daily time series and anomalies (referenced to 1988-2006 means) of: (a) the daily melting index; (b) surface air temperature and (c) 1000-500 hPa thickness from the NCEP/NCAR reanalysis for 1 June-31 August 2007, averaged over the area in Greenland showing peak positive melting day anomalies (see box in Fig. 1a). Daily values are shown as black lines (right hand scales) while coloring refers to anomalies (left-hand scales).

cloud optical thickness (not shown), anomalies of incoming shortwave radiation (d) are negative over most of Greenland, particularly over its western side where they may exceed $-15 \mathrm{~W} \mathrm{~m}^{-2}$. Finally, it is clear that surface albedo (e) was below average almost everywhere, but especially along the ice sheet margin (down to $-30 \%$ ).

The positive anomalies in surface air temperature and downwelling longwave radiation simulated with the MAR are consistent with the melt pattern shown in Fig. 1a. Although anomalies in shortwave radiation were slightly negative, the MAR results point to a countering effect by reduced surface albedo. To help further understand the record melt event from the viewpoint of the surface energy budget, the remaining panels in Fig. 2 show MAR-based anomaly maps of the fluxes of latent heat (f), sensible heat (g), net longwave radiation (h), net shortwave radiation (i) and the net surface energy flux (j), the latter representing the sum of the radiation terms and the two turbulent heat fluxes (sensible and latent). Positive anomalies mean more energy to the surface.
Anomalies of the latent heat flux are generally small. Those of sensible heat are positive (locally exceeding $20 \mathrm{~W} \mathrm{~m}^{-2}$ ) along the west margin of the ice sheet and generally small over the interior section except for the westcentral portion, where negative values of $-5-10 \mathrm{~W} \mathrm{~m}^{-2}$ are found. Pointing to the dominant effects of reductions in surface albedo compared to cloud cover, anomalies in net shortwave radiation are strongly positive along the coast (more than $20 \mathrm{~W} \mathrm{~m}^{-2}$ ). Despite negative anomalies in the downwelling shortwave flux, positive anomalies in net shortwave $\left(5-15 \mathrm{~W} \mathrm{~m}^{-2}\right)$ also dominate most of the ice sheet except elevations higher than $2500 \mathrm{~m}$. Anomalies in net longwave radiation to the surface are strongly positive and significant over the southwest part of the ice sheet.

The overall result is strong positive significant anomalies in the net surface energy flux over the western part of the ice sheet, consistent with the location of large melting anomalies (Figs. 1a and 3). These positive net surface energy flux anomalies are in turn driven by the combined effects of positive anomalies in net longwave radiation, sensible heat and 

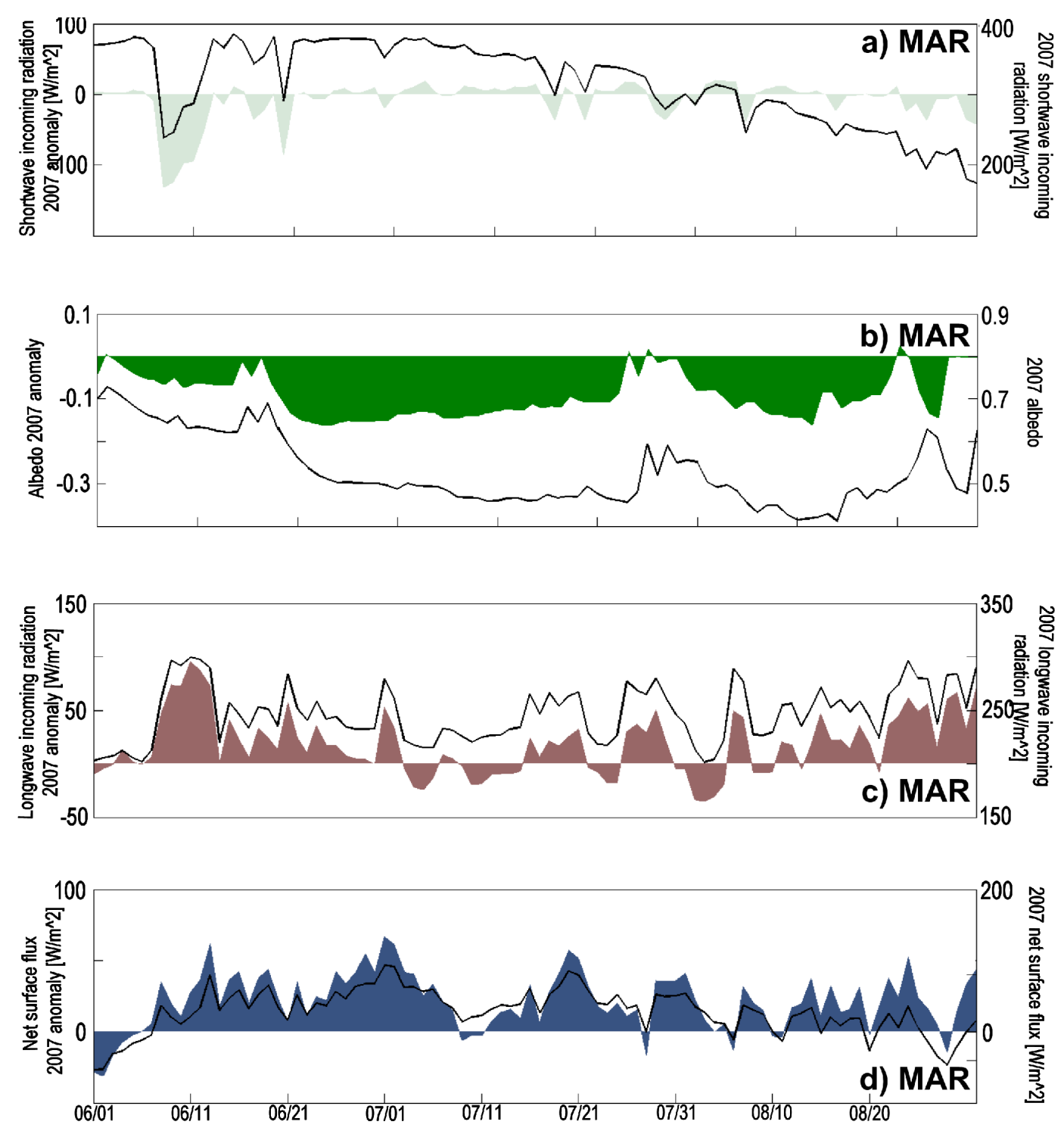

Fig. 5. Same as Fig. 4 but for (a) incoming shortwave radiation; (b) albedo; (c) incoming longwave radiation and (d) the net surface energy flux simulated by the MAR model. As in Fig. 3, anomalies are with respect to 1988-2006.

net shortwave radiation, the latter linked to negative albedo anomalies. While the albedo anomalies are themselves consistent with the effects of strong melt on increasing snow grain size, their presence in the MAR outputs may also be a consequence of low simulated snow accumulation over the winter of 2006-2007 (Fettweis, 2007). As melt progressed, it may have exposed bare ice (in the lower elevations) and old snow sooner than in previous years (such processes are treated in the MAR framework).

It is useful to focus further on the region over southwestern Greenland where the most extreme positive melting anomalies occurred. This region $\left(64.5-67^{\circ} \mathrm{N}, 50-47.5^{\circ} \mathrm{W}\right)$, where the melt duration was 25-30 days above average, is bounded by the square shown in Fig. 1a. It coincides closely to the area of peak melting day anomalies shown by Mote (2007).

For this analysis, we assess daily values and anomalies of the MI $\left(\mathrm{km}^{2} \times\right.$ days $)$ from SSM/I, NCEP/NCAR estimates of surface air temperature (K) and 1000-500 hPa thickness (m). These are complemented by time series from the MAR of downwelling longwave and shortwave radiation $\left(\mathrm{W} \mathrm{m}^{-2}\right)$, albedo, and the net surface energy flux $\left(\mathrm{W} \mathrm{m}^{-2}\right)$. Time series from SSM/I and NCEP/NCAR averaged over the study region are plotted in Fig. 4 for 1 June through 31 August. As before, anomalies are with respect to 1988-2006. The 
$1000-500 \mathrm{hPa}$ thickness is proportional to the mean temperature of that pressure interval, providing information on lower tropospheric warmth to complement the surface air temperature estimates.

The MI, surface air temperature and thickness anomalies (Fig. $4 \mathrm{a}-\mathrm{c}$ ) are persistently positive through the summer period, with strong imprints of variability at synoptic timescales. The linear correlation between the daily MI and thickness anomalies is 0.79; values for individual summers from 1979 through 2007 range from 0.74 to 0.84 . Results from MAR show a mix of positive and negative anomalies in the shortwave radiation flux incident to the surface (Fig. 5a), with strong negative values early in the record. Averaged for the summer, the shortwave flux was slightly $\left(4 \mathrm{~W} \mathrm{~m}^{-2}\right)$ below the mean. Anomalies in simulated albedo are persistently negative. The prominent spikes in albedo, centered around 11 July and 12 August, represent snowfall event. Such events in MAR are described by Fettweis et al. (2005). As expected, modeled anomalies in the incident longwave radiation are persistently positive (Fig. 5c).

\section{Conclusions and discussion}

We conclude that the record Greenland surface melt in summer 2007 identified by Tedesco (2007a) and Mote (2007) is a reflection of unusually warm conditions, seen in anomalies of surface air temperature, $1000-500 \mathrm{hPa}$ atmospheric thickness and modeled fields of downwelling longwave radiation and the surface sensible heat flux. These effects, along with reduced surface albedo, are manifested in consistently positive anomalies in the modeled net surface heat flux through the summer season. The 2007 melting index was 2.1 standard deviations (Z-scores) above the mean. However, given the short record available from SSM/I and SMMR, the question of whether this melt event is outside of the envelope of natural variability cannot be readily addressed.

Evidence is now strong that the Greenland ice sheet, like the Arctic sea ice cover, is responding to atmospheric greenhouse gas loading (e.g., Stroeve et al., 2007; Hanna et al., 2008a). As introduced earlier, the record surface melt over Greenland in 2007 was attended by a record low in summer Arctic sea ice extent. The latter represents response to thinning of the ice pack over recent decades, accentuated by an unusual atmospheric pattern in summer 2007, featuring high pressure over the central Arctic Ocean and low pressure over central and western Siberia. Resultant southerly winds promoted high temperatures north of Siberia and transport of ice away from the Siberian coast (Stroeve et al., 2008). The NCEP/NCAR data also document southerly airflow over the southwestern part of the Greenland ice sheet (Fig. 6), consistent with the region of strongest melt. Hanna et al. (2008b) argue that $500 \mathrm{hPa}$ geopotential height anomalies over Greenland in summer 2007 were exceptional with respect to the 60 year NCEP/NCAR record. However this

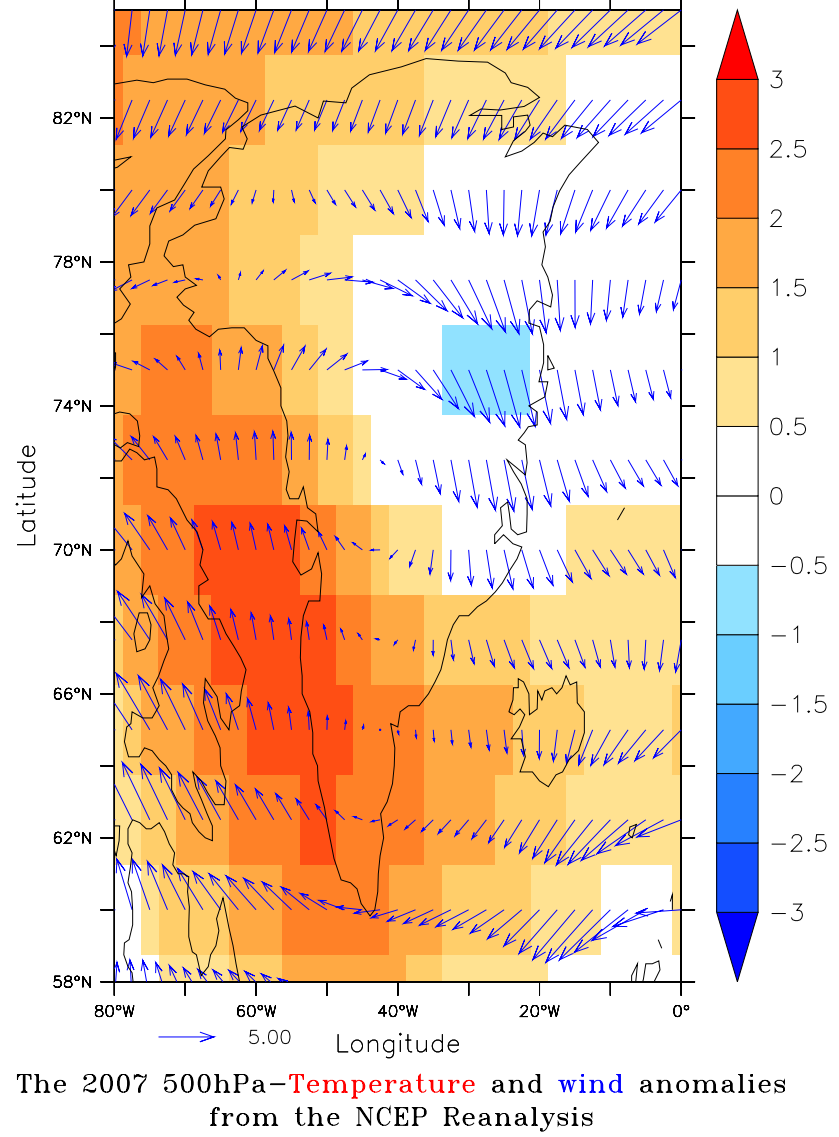

Fig. 6. Temperature and wind anomalies for June-August 2007 (referenced to 1988-2006 means) at 500 hPa from the NCEP/NCAR Reanalysis. The blue arrow below the plot represents a wind anomaly of $5 \mathrm{~m} / \mathrm{s}$.

exceptional regional circulation pattern shows no obvious link to the pattern associated with the sea ice loss The common factor was that both the sea ice cover and Greenland were under the influence of warm conditions. Indeed, warm conditions were pervasive over northern high latitudes, contributing strongly to the global-averaged temperature in 2007 being the second highest of the instrumental record according to the Goddard Institute for Space Sciences analysis (http://data.giss.nasa.gov/gistemp/2007/).

While melting at high elevations is not directly contributing to runoff and sea level rise, it leads to a reduction in ice sheet albedo. Interestingly, the 2007 surface mass balance over the ice sheet of $-65 \mathrm{~km}^{3} / \mathrm{yr}$ as simulated by the MAR is the most negative of the period 1979-2007 (Fettweis, 2007). While strong melt contributed to this negative modeled mass balance anomaly, a large contribution came also from anomalously low snowfall $\left(508 \mathrm{~km}^{3} / \mathrm{yr}\right.$ water equivalent which corresponds to about $80 \%$ of the mean precipitation) (Hanna et al., 2008b). The simulated Equilibrium Line Altitude (ELA) 
averaged over the period $1988-2006$ and for 2007 is plotted in Fig. 3. Note how the ELA is higher in 2007 over the western side of the ice sheet. Mote (2007) noted that while the seasonal melt departure index is significantly correlated with summer temperatures at coastal stations around Greenland, 2007 showed more melt than expected based on these records. The MAR simulation lends credence to his suggestion for a role of reduced albedo.

Acknowledgements. This study was supported by NSF grants ARC-0531040, ARC-0531302, UMBC grants 125310140022 $00002322,1253 \quad 10140 \quad 02200002264$ and $1253 \quad 10140 \quad 022$ 00002262, the NASA Crysophere program and the NASA Terrestrial Hydrology program and the City College of the City University of New York.

Edited by: J. L. Bamber

\section{References}

Armstrong, R. L., Knowles, K. W., Brodzik, M. J., and Hardman, M. A.: updated current year. DMSP SSM/I Pathfinder Daily EASE-Grid Brightness Temperatures [1988-2007], Boulder, Colorado USA, National Snow and Ice Data Center, digital media, 1994.

Abdalati, W. and Steffen, K.: Snowmelt on the Greenland Ice Sheet as derived from passive microwave satellite data, J. Climate, 10, 241-251, 1997.

Box, J. E., Bromwich, D. H., and Bai, L.-S.: Greenland ice sheet surface mass balance for 1991-2000: application of Polar MM5 mesoscale model and in-situ data, J. Geophys. Res., 109(D16), D16105, doi:10.1029/2003JD004451, 2004.

Comiso, C., Parkinson, C. L., Gerttsen, R., and Stock, L.: Accelerated decline in the Arctic sea ice cover, Geophys. Res. Lett., 35, L01703, doi:10.1029/2007GL031972, 2008.

De Ridder, K. and Gallée, H.: Land surface-induced regional climate change in Southern Israel, J. Appl. Meteorol., 37, 14701485, 1998.

Fettweis, X., Gallée, H., Lefebre, L., and van Ypersele, J.-P.: Greenland surface mass balance simulated by a regional climate model and comparison with satellite derived data in 1990-1991, Clim. Dynam., 24, 623-640, doi:10.1007/s00382-005-0010-y, 2005.

Fettweis, X.: Reconstruction of the 1979-2006 Greenland ice sheet surface mass balance using the regional climate model MAR, The Cryosphere, 1, 21-40, 2007, http://www.the-cryosphere.net/2/117/2008/tc-2-117-2008.html.
Gallée, H. and Schayes, G.: Development of a three-dimensional meso- $\gamma$ primitive equations model, Mon. Wea. Rev., 122, 671$685,1994$.

Hanna, E., Huybrechts, P., Steffen, K., Cappelen, J., Huff, R., Shuman, C., Irvine-Fynn, T., Wise, S., and Griffiths, M.: Increased runoff from melt from the Greenland Ice Sheet: a response to global warming, J. Climate 21, 331-341, doi:10.1175/2007JCLI1964.1., 2008a.

Hanna, E., Cappelen, J., Fettweis, X., Huybrechts, P., Luckman, A., and Ribergaard, M. H.: Hydrologic response of the Greenland Ice sheet: the role of oceanographic warming, Hydrological Processes, in press, 2008b.

Kalnay, E., Kanamitsu, M., Kistler, R., Collins W., et al.: The NCEP/NCAR 40-year reanalysis project, Bull. Amer. Meteor. Soc., 77, 437-470, 1996.

Lefebre, F., Gallée, H., van Ypersele, J., and Greuell, W.: Modeling of snow and ice melt at ETH Camp (West Greenland): A study of surface albedo, J. Geophys. Res., 108(D8), 4231, doi:10.1029/2001JD001160, 2003

Mote T. L.: Greenland surface melt trends 1973-2007: Evidence of a large increase in 2007, Geophys. Res. Lett., 34, L22507, doi:10.1029/2007GL031976, 2007.

Mote, T. L. and Anderson, M. R.: Variations in snowpack melt on the Greenland ice sheet based on passive microwave measurements, J. Glaciol., 41, 51-60, 1995.

Serreze, M. C., Holland, M. M., and Stroeve, J.: Perspectives on the Arctic's shrinking sea ice cover, Science, 315, 1533-1536, 2007.

Steffen, K., Nghiem, S. V., Huff, R., and Neumann, G.: The melt anomaly of 2002 in the Greenland Ice Sheet from active and passive microwave satellite observations, Geophys. Res. Lett., 31, L20402, doi:10.1029/2004GL020444, 2004.

Stroeve, J., Serreze, M., Drobot, S., Gearheard, S., Holland, M., Maslanik, J., Meier, W., and Scambos, T.: Arctic sea ice plummets in 2007, EOS, Trans. Am. Geophys. Union, 89, 13-14, 2008.

Tedesco M.: A new record in 2007 for melting in Greenland, EOS, Trans. Am. Geophys. Union, 88(39), doi:10.1029/2007EO390003, 2007a.

Tedesco, M.: Snowmelt detection over the Greenland ice sheet from SSM/I brightness temperature daily variations, Geophys. Res. Lett., 34, L02504, doi:10.1029/2006GL028466, 2007 b.

Ulaby, F. and Stiles, W.: The active and passive microwave response to snow parameters, 2: water equivalent of dry snow, J. Geophys. Res., 85, 1045-1049, 1980.

Van den Broeke, M., Smeets, P., Ettema, J., Van der Veen, C., Van de Wal, R., and Oerlemans, J.: Partitioning of melt energy and meltwater fluxes in the ablation zone of the west Greenland ice sheet, The Cryosphere Discuss., 2, 711-736, 2008, http://www.the-cryosphere-discuss.net/2/711/2008/ tcd-2-711-2008.html. 